\title{
International Trade and Export Promotion in Rwanda: A Case of Technical Barriers to Trade National Enquiry Point
}

\author{
Kwizera Simeon $^{1}$ and Mercyline Kamande ${ }^{2}$
}

\author{
${ }^{1}$ School of Social Sciences, Mount Kenya University \\ Kigali, Rwanda \\ ${ }^{2}$ School of Business and Economics, Mount Kenya University \\ Kigali, Rwanda
}

\begin{abstract}
The study examined the role of international trade on export promotion in Rwanda. Descriptive and correlational research designs were used. A sample size of 119 respondents was selected using simple random and purposive sampling techniques. Information was gathered using questionnaires, interview guide and document review. Statistical Package for Social Sciences was used. Results suggested a significant correlations between trade agreements and increased volume of exports $\left(\mathrm{r}=.167^{*}, \mathrm{p}=.078\right)$, increase of value from export $(\mathrm{r}=$ $\left..393^{*}, \quad \mathrm{p}=.000\right), \quad$ profitability $\left(\mathrm{r}=.560^{*}, \quad \mathrm{p}=.056\right)$.A negative correlation was between trade promotion measures and export volume $\left(\mathrm{r}=.-050^{*}, \mathrm{p}=.602\right)$, value of export $\left(\mathrm{r}=.-159^{*}, \mathrm{p}=.093\right)$, but it was positive for export profitability $\left(\mathrm{r}=.167^{*}\right.$, $\mathrm{p}=.078$ ). This study recommends an increased awareness on technical barriers to trade, a partnership between Government trade agencies and the Private Sector Federation to ensure that policies that regulate export sector are harmonized. A similar study to be carried out from multiple groups of informants from diversified clusters to come up with a variety of results. Further studies may be undertaken using longitudinal research in order to assess factors that contribute to international trade and export promotion in Rwanda.

Key word: International Trade, Technical Barrier to Trade, Trade Promotion, National Enquiry Point
\end{abstract}

\section{Introduction}

The international development relies on factors such as social, political, economic (Ahmed, 2011). Bruckner and Daniel (2012) recall that states are no longer self-sufficient and an increase is observed in trade relations between the North-South/East-West and South-South poles. Nations are engaged in relations to exchange what they produce and to purchase what they need. Burstein and Melitz, (2013) argue that international trade institutions were created, namely General Agreement on Tariffs and Trade (GATT), International Trade Center (ITC) and World Trade Organization (WTO).

The World Trade Organization (WTO) Agreement on Technical Barriers to Trade (TBT) was enacted on $1^{\text {st }}$ January 1995. Chidede (2018) holds that the Agreement advocates for removal of TBTs and requests for establishment of a National Enquiry Point by every member of the WTO. Rwanda Standards Board was designated to be the WTO/TBT National Enquiry Point in 2005.

The greatest impediments for export promotion in Rwanda include market scarcity, lack of access to foreign market and protectionism on trade. Trade data from the National Bank of Rwanda (2018) confirmed that Rwanda's economic resilience is boosted by domestic market and export. The Bank's report holds that Made in Rwanda campaign in 2015 contributed to export by $69 \%$ from about US\$ 559 million in 2015 to nearly US\$ 944 million in 2017 while imports decreased by $4 \%$, from US\$ 1.849 billion in 2015 to US\$ 1.772 billion in 2017. Since 2015 , the country experienced a $36 \%$ decrease in its trade deficit (WTO, 2018). Rwanda's exports to African countries are estimated at $58.7 \%$, exports to Asia are $22.1 \%$, exports to Europe stand at $15.5 \%$ whereas exports to North America are $3.1 \%$ (Rwanda Revenue Authority [RRA], 2012). In the review, no study was seen discussing the of National Enquiry Point, Rwanda. This study was carried out based on these objectives:

i) To assess the effect of trade agreements on export promotion in Rwanda. 
ii) To evaluate the effects of trade promotion on export promotion in Rwanda

iii) To examine the effects of country cooperation on export promotion in Rwanda.

\section{Literature review}

A report of World Bank and WTO (2015) holds that the trade agreement increased the export volumes by 28 percent and export value by $16 \%$ between 2010 and 2014. Burger and Linders (2009) revealed an increase of $35 \%$ of business environment in Maghreb union. Egger and Michael (2014) showed trade creation and diversion, static welfare analysis.

Fontagné and Mitaritonna (2011) contended that ECOWAS trade agreements are profitable for export by $19 \%$ in term of profitability from export volume between 2006 and 2010.

He (2013) reiterates the role of country to country relations in export volume, $3.9 \%$ of increase was observed. Kanyimbo and Manduna (2013) denote general trade effects of regional trade agreements in competition framework.

WTO (2017) asserts that treaties sets up take part in achieving Sustainable Development Goal. O'Neil (2016) notes that exporters do not benefit at the same level because it depends on export finished products or raw materials. Daniel, et al. (2017) reiterate that difficult trade procedures enhance documentation processes for trade transactions. Insufficient customs facilities and poor use of information technology were pertinent hindrances. Seetanah, et al. (2013) hold that Article 69 of TRIPS provides for customs cooperation against trade in goods, forged trademark goods and plagiarized copyrights goods. Snorrason (2012) adds that Article 12 of the Agreement on Trade Facilitation sets forth comprehensive rules on customs cooperation.

Rose (2007); Subramanian and Wei (2007); Büthe and Milner (2014); Donna and Hocking (2010) argue that international trade was beneficial to export promotion. However, the critical review results showed that there are still shortcomings. In the review, no study was seen discussing the WTO roles in relation with National Enquiry Point in a given country.

\section{Materials and Methods}

This study used descriptive and correlational methods. It used quantitative and qualitative strategies to provide the correlation between development cooperation strategies and business development in Rwanda.

The study targeted 168 traders identified in Rwanda Revenue Annual Report of the year 2018. The following export business clusters were selected: agro-processing, tea, coffee, cassava and horticulture products. Thus, a sample of 119 export businesses calculated using Yamane formula.

$\operatorname{Eq}(1)$ :

$n=\frac{N}{1+N(e)^{2}}=\frac{168}{1+168(0.05)^{2}}=118.3098591$ Where: $\mathrm{n}=$ Sample Size, $\mathrm{N}=$ Sampled population, $\mathrm{e}=$ Margin of Error selected at 5\%.The estimated target population is $\mathrm{N}=168$ traders.

Selection of participants followed the simple random sampling method. The lists were shuffled using Ms. Excel and the first numbers proportionate to the targeted sample size was considered. The purposive sampling was used to acquire 5 key informants with needed information.

For quantitative information, a questionnaire helped to obtain responses to objectives. Analyzing of data were done using Statistical Package for Social Sciences (SPSS) while qualitative information was analyzed sung content analysis.

\section{Results and discussion}

The study assessed effects of trade agreements on export promotion in Rwanda, evaluated effects of trade promotion measures on export promotion in Rwanda, and examined effect of country cooperation on export promotion in Rwanda.

Results in Table 4.1 indicated that $37.5 \%$ accorded very large extent score to the effect of removal of duties, $48.2 \%$ reported large extent effect accounted to the reduction of export tariff fixed on an exported product $55.4 \%$ acknowledged large extent effect that export licenses have as restriction on the quantity of goods that may be exported. $60.7 \%$ attributed very large extent to the fact that trade quotas were reduced/ removed while $49.1 \%$ evidenced a reduction of production subsidies 


\subsection{Trade Agreements Parameters Adopted for Trade Promotion in Rwanda}

Table 4.1Trade Agreements Parameters.

\begin{tabular}{|c|c|c|c|c|c|c|c|c|c|c|c|c|c|}
\hline \multirow[b]{2}{*}{ Statement } & \multicolumn{2}{|c|}{ Not all } & \multicolumn{2}{|c|}{$\begin{array}{l}\text { Small } \\
\text { extent }\end{array}$} & \multicolumn{2}{|c|}{ Moderate } & \multicolumn{2}{|c|}{$\begin{array}{l}\text { Large } \\
\text { extent }\end{array}$} & \multicolumn{2}{|c|}{$\begin{array}{c}\text { Very large } \\
\text { extent }\end{array}$} & \multirow[b]{2}{*}{$\mathbf{N}$} & \multirow{2}{*}{$\begin{array}{l}\text { Total } \\
\text { Mean }\end{array}$} & \multirow[b]{2}{*}{ Sd } \\
\hline & $\mathbf{N}$ & $\%$ & $\mathbf{N}$ & $\%$ & $\mathbf{N}$ & $\%$ & $\mathbf{N}$ & $\%$ & $\mathbf{N}$ & $\%$ & & & \\
\hline Removal of duties & 12 & 10.7 & 10 & 8.9 & 9 & 8.0 & 42 & 37.5 & 39 & 34.8 & 112 & 3.7 & 1.3 \\
\hline Export tariff fixed & 14 & 12.5 & 7 & 6.2 & 8 & 7.1 & 29 & 25.9 & 54 & 48.2 & 112 & 3.9 & 1.3 \\
\hline Export licenses & 1 & 0.9 & 9 & 8.0 & 5 & 4.5 & 62 & 55.4 & 35 & 31.2 & 112 & 4.0 & 0.8 \\
\hline Trade quotas & 1 & 0.9 & 5 & 4.5 & 6 & 5.4 & 32 & 28.6 & 68 & 60.7 & 112 & 4.4 & 0.8 \\
\hline Production subsidies & 4 & 3.6 & 6 & 5.4 & 3 & 2.6 & 55 & 49.1 & 44 & 39.3 & 112 & 4.1 & 0.9 \\
\hline $\begin{array}{l}\text { Domestic Contents } \\
\text { Requirements }\end{array}$ & 11 & 9.8 & 12 & 10.7 & 20 & 17.9 & 29 & 25.9 & 40 & 35.7 & 112 & 3.6 & 1.3 \\
\hline
\end{tabular}

Source: Primary data (2020)

\subsection{Trade Promotion Measures Adopted for Export Promotion}

Table 4.2 Effects of trade promotion on export promotion

\begin{tabular}{|c|c|c|c|c|c|c|c|c|c|c|c|c|c|}
\hline \multirow[b]{2}{*}{ Statement } & \multicolumn{2}{|c|}{ Not all } & \multicolumn{2}{|c|}{$\begin{array}{l}\text { Small } \\
\text { extent }\end{array}$} & \multicolumn{2}{|c|}{ Moderate } & \multicolumn{2}{|c|}{$\begin{array}{l}\text { Large } \\
\text { extent }\end{array}$} & \multicolumn{2}{|c|}{$\begin{array}{c}\text { Very large } \\
\text { extent }\end{array}$} & \multirow[b]{2}{*}{$\mathbf{N}$} & \multirow{2}{*}{$\begin{array}{l}\text { Total } \\
\text { Mean }\end{array}$} & \multirow[b]{2}{*}{ Sd } \\
\hline & $\mathbf{N}$ & $\%$ & $\mathbf{N}$ & $\%$ & $\mathbf{N}$ & $\%$ & $\mathbf{N}$ & $\%$ & $\mathbf{N}$ & $\%$ & & & \\
\hline $\begin{array}{ll}\text { Simplification } & \text { of } \\
\text { customs processes } & \end{array}$ & 10 & 8.9 & 5 & 4.5 & 5 & 4.5 & 36 & 32.1 & 56 & 50.0 & 112 & 4.0 & 1.2 \\
\hline Improve transparency & 13 & 0 & 0.0 & 0 & 4 & 3.6 & 52 & 46.4 & 43 & 38.4 & 112 & 4.0 & 1.2 \\
\hline certification procedures & 21 & 18.8 & 6 & 5.4 & 8 & 7.1 & 26 & 23.2 & 51 & 45.5 & 112 & 3.7 & 1.5 \\
\hline $\begin{array}{l}\text { Regulatory } \\
\text { practice }\end{array}$ & 5 & 4.5 & 8 & 7.1 & 32 & 28.6 & 46 & 41.1 & 21 & 18.8 & 112 & 3.6 & 1.0 \\
\hline $\begin{array}{l}\text { Promote fair trade } \\
\text { among countries }\end{array}$ & 8 & 7.1 & 7 & 6.2 & 6 & 5.4 & 42 & 37.5 & 49 & 43.8 & 112 & 4.0 & 1.1 \\
\hline $\begin{array}{l}\text { Access to information } \\
\text { about destination } \\
\text { market requirements }\end{array}$ & 11 & 9.8 & 4 & 3.6 & 2 & 1.8 & 54 & 48.2 & 41 & 36.6 & 112 & 3.9 & 1.1 \\
\hline
\end{tabular}

Source: Primary data (2020)

The study felt that,50.0\% show a large extent the simplification of customs processes has on export promotion, $46.4 \%$ accounted large extent effecting the improvement of transparency in cross-border trade, $45.5 \%$ argued that reduced time to access service for standards, product testing and certification as well as continuous awareness raising on service delivery procedures are a boost to exports

\subsection{Countries Relations Measures Adopted for Export Promotion} Table 4.3 Countries Relations on Export Promotion

\begin{tabular}{|c|c|c|c|c|c|c|c|c|c|c|c|c|c|}
\hline \multirow[b]{2}{*}{ Statements } & \multicolumn{2}{|c|}{ Not at All } & \multicolumn{2}{|c|}{$\begin{array}{c}\text { Small } \\
\text { Extent }\end{array}$} & \multicolumn{2}{|c|}{ Moderate } & \multicolumn{2}{|c|}{$\begin{array}{l}\text { Large } \\
\text { Extent }\end{array}$} & \multicolumn{2}{|c|}{$\begin{array}{c}\text { Very Large } \\
\text { Extent }\end{array}$} & \multirow[b]{2}{*}{$\mathbf{N}$} & \multirow{2}{*}{$\begin{array}{l}\text { Total } \\
\text { Mean }\end{array}$} & \multirow[b]{2}{*}{ Sdv } \\
\hline & $\mathbf{N}$ & $\%$ & $\mathbf{N}$ & $\%$ & $\mathbf{N}$ & $\%$ & $\mathbf{N}$ & $\%$ & $\mathbf{N}$ & $\%$ & & & \\
\hline $\begin{array}{l}\text { Mutual administrative } \\
\text { assistance }\end{array}$ & 8 & 6.1 & 30 & 26.2 & 6 & 5.2 & 36 & 32.1 & 32 & 28.6 & 112 & 3.4 & 1.3 \\
\hline $\begin{array}{l}\text { Single administrative } \\
\text { document }\end{array}$ & 11 & 9.8 & 18 & 16.1 & 3 & 2.7 & 35 & 31.2 & 45 & 40.2 & 112 & 3.7 & 1.3 \\
\hline $\begin{array}{l}\text { Mutual recognition of } \\
\text { quality marks }\end{array}$ & 11 & 9.8 & 15 & 13.4 & 12 & 10.7 & 34 & 30.4 & 40 & 35.7 & 112 & 3.6 & 1.3 \\
\hline $\begin{array}{l}\text { Agreement on the Rules } \\
\text { of Origin }\end{array}$ & 3 & 2.7 & 20 & 17.9 & 20 & 17.9 & 19 & 17.0 & 57 & 44.6 & 112 & 3.8 & 1.2 \\
\hline $\begin{array}{l}\text { Mutual Recognition on } \\
\text { Standards }\end{array}$ & 14 & 12.5 & 33 & 29.5 & 5 & 4.5 & 19 & 17.0 & 41 & 36.6 & 112 & 3.3 & 1.5 \\
\hline Mutual trade facilitation & 16 & 9.0 & 25 & 28.3 & 8 & 7.9 & 29 & 19.3 & 34 & 35.9 & 112 & 3.3 & 1.4 \\
\hline
\end{tabular}


Source; Primary data $\mathbf{( 2 0 2 0 )}$

Results found that $40.2 \%$ attribute very large extent to the use of a single administrative document, $35.7 \%$ attributed large extent to the effect that mutual recognition of quality marks and standards has in promoting exports among trading countries, $44.6 \%$ accorded very large extent effect to establishing agreement on the rules of origin of products among the trading countries and regional and international trade blocks.

\subsection{Export Volumes between 2015 and 2019}

Table 4.4Estimated Export Volume from 2015-2019

\begin{tabular}{lrrrr}
\hline \multicolumn{1}{c}{ Kind of Export Goods } & \multicolumn{1}{c}{$\mathbf{2 0 1 6}$} & $\mathbf{2 0 1 7}$ & $\mathbf{2 0 1 8}$ & $\mathbf{2 0 1 9}$ \\
\hline Coffee & $18,499,982$ & $18,502,442$ & $19,560,636$ & $20,353,423$ \\
Tea & $24,860,386$ & $25,128,967$ & $25,134,567$ & $27,824,246$ \\
Pyrethrum & 9329 & 9,329 & 22,404 & 23,262 \\
Vegetables & $16,620,941$ & $19,227,263$ & $19,227,264$ & $20,635,174$ \\
Fruits & $3,645,844$ & $5,918,322$ & $5,918,322$ & $8,757,395$ \\
Flowers & 2,974 & $177,660.6$ & $177,661.0$ & 704,736 \\
Hides and Skins & $3,400,949$ & $6,345,145$ & $6,345,145$ & $6,781,532$ \\
Meat & $5,310,472$ & $6,237,017$ & $6,237,017$ & $7,021,167$ \\
Dairy & $12,081,956$ & $12,081,956$ & $12,732,335$ & $17,514,192$ \\
Live Animals & 941,046 & $1,139,227$ & $1,139,227$ & $1,510,058$ \\
Cereals(Grains \& Flours) & $54,724,337$ & $141,959,696$ & $141,959,696$ & $237,686,941$ \\
Pulses & $16,995,500$ & $16,995,500$ & $18,893,861$ & $28,563,820$ \\
\hline
\end{tabular}

Source: NAEB Report (2020)

The study assessed the export volumes between 2015 and 2019.The number of exports is the export volume. It indicate that $41.1 \%$ were able to export goods estimated between 1,000 and 10,000 Tones,
$25.9 \%$ exported between 10,000 and 20,000 tones, $17.9 \%$ exported between 20,000 and 30,000 tones, $15.2 \%$ were able to export less than 1000 tones.

\subsection{Export Value between 2015 and 2019}

Table 4.5 Value earned by sampled companies from export between 2015-2019

\begin{tabular}{lccll}
\hline & \multicolumn{1}{c}{2016} & \multicolumn{1}{c}{2017} & \multicolumn{1}{c}{2019} \\
\hline Coffee & $60,718,061$ & $58,526,023$ & $58,586,314$ & $69,359,159$ \\
Tea & $70,773,796$ & $74,548,304$ & $74,571,123$ & $88,069,066$ \\
Pyrethrum & $4,117,754$ & $1,655,350$ & $1,655,350$ & $3,774,824$ \\
Vegetables & $4,481,695$ & $11,001,766$ & $11,001,766$ & $12,389,352$ \\
Fruits & $1,315,871$ & $4,584,972$ & $4,584,972$ & $6,890,737$ \\
Flowers & 13,428 & $1,243,427$ & $1,243,427$ & $4,159,785$ \\
Hides and Skins & $7,411,684$ & $7,957,948$ & $7,957,948$ & $\mathbf{5 , 8 5 3 , 7 5 5}$ \\
Meat & $17,663,941$ & $22,906,406$ & $22,906,406$ & $\mathbf{2 4 , 7 8 4 , 2 4 5}$ \\
Dairy & $12,758,452$ & $13,061,738$ & $\mathbf{1 3 , 0 6 1 , 7 3 8}$ & $\mathbf{2 0 , 6 4 4 , 9 4 0}$ \\
Live Animals & $34,513,109$ & $27,001,980$ & $27,001,980$ & $28,528,975$ \\
Cereals(Grains \& Flours) & $27,680,463$ & $68,040,167$ & $68,040,167$ & $104,258,040$ \\
Pulses & $34,513,109$ & $10,095,956$ & $10,095,956$ & $15,022,428$ \\
\hline
\end{tabular}

Source: NAEB (2020).

Coffee exports volume of the FY 2017-2018, increased by $10 \%$ compared to the same period of the FY 2017-2018. This increase is attributed in the increase of the production by $19 \%$. Export revenues increased by $18.4 \%$ due to some good average prices in some months and increased exports volume. 


\subsection{Profitability of Exports between 2015 and 2019}

Table 4.6Estimate profitability of exports from 2015 to 2019 in term of \% change Values

\begin{tabular}{lcccc}
\hline & $\mathbf{2 0 1 6}$ & $\mathbf{2 0 1 7}$ & $\mathbf{2 0 1 8}$ & $\mathbf{2 0 1 9}$ \\
\hline Coffee & -4 & -5 & 2 & 18.39 \\
Tea & 5 & 14 & 15 & 18 \\
Pyrethrum & -60 & -13 & 3 & 20 \\
Vegetables & -145 & 4 & 10 & 12.61 \\
Fruits & -248 & -13 & 13 & 50.29 \\
Flowers & - & -37 & 37 & 39.5 \\
Hides and Skins & 7 & 12 & 17 & 26.44 \\
Meat & -16 & -16 & 6.2 & 8.2 \\
Dairy & 2 & 1.3 & 45 & 58.06 \\
Live Animals & -22 & -38 & 1.5 & 5.66 \\
Cereals(Grains \& & -46 & & 38 & 53.23 \\
Flours) & -11 & 16 & 26 & 48.8 \\
Pulses & & & & 5 \\
\hline
\end{tabular}

Source: NAEB Report (2020).

It is estimated to $27,824,251 \mathrm{~kg}$ in $2017-2018$ compared with $25,128,967 \mathrm{~kg}$ performed in 20162017. Income value was estimated to 23.3.17 USD per $\mathrm{kg}$ but was .97 USA per $\mathrm{kg}$ in 2016-2017. The size of export was asserted as a result of supports given to exporters by NAEB.

\subsection{Correlation Analysis}

Table 4.7 Correlation between independent and dependent variables

\begin{tabular}{|c|c|c|c|c|}
\hline & & Export Volume & Value & Profitability \\
\hline \multirow{3}{*}{$\begin{array}{l}\text { Trade Agreements } \\
\text { parameters }\end{array}$} & Pearson Correlation & .167 & $.393^{* *}$ & .560 \\
\hline & Sig.(2-tailed) & .078 & .000 & .056 \\
\hline & $\mathrm{N}$ & 112 & 112 & 112 \\
\hline \multirow{3}{*}{$\begin{array}{l}\text { Trade Promotion } \\
\text { measures }\end{array}$} & Pearson Correlation & -.050 & -.159 & .167 \\
\hline & Sig. (2-tailed) & .602 & .093 & .078 \\
\hline & $\mathrm{N}$ & 112 & 112 & 112 \\
\hline \multirow[t]{3}{*}{ Country Relations } & Pearson Correlation & .032 & .058 & -.041 \\
\hline & Sign.(2-tailed) & .741 & .545 & .669 \\
\hline & $\mathrm{N}$ & 112 & 112 & 112 \\
\hline
\end{tabular}

Source: Primary data (2020).

The correlation suggested significant correlations between trade agreements and increased volume of exports $\left(\mathrm{r}=.167^{*}, \mathrm{p}=.078\right)$, increase of value from export $(\mathrm{r}=.393 *, \mathrm{p}=.000)$, and profitability $(\mathrm{r}=.560 *$, $\mathrm{p}=.056)$.

A negative correlation was between trade promotion measures and export volume $\left(\mathrm{r}=.-050^{*}, \mathrm{p}=.602\right)$, value of export $\left(\mathrm{r}=.-159^{*}, \mathrm{p}=.093\right)$, but it was positive for export profitability $\left(\mathrm{r}=.167^{*}\right.$, $\mathrm{p}=.078$ ). Finally, Significant correlations were found between country relations and export volume $\left(\mathrm{r}=.032^{*}, \mathrm{p}=.741\right)$, export value $\left(\mathrm{r}=.058^{*}, \mathrm{p}=.549\right)$ and profitability $\left(\mathrm{r}=-0.041^{*}, \mathrm{p}=.669\right)$.

\section{Discussion}

This study concurs with Ahmed (2011) who affirms that a domestic subsidy is often granted to producers of import-competition goods and export subsidies. This study concurred with Rose (2007) that the presence of local obligations and limitations may be and lead to cost and to capital, revenue, break of services, cost overruns, plan to postpone procedures in exporting promotional process and repairing costs.

This study is relevant to Kanyimbo and Manduna (2013) who emphasize the potential for countries relations on export promotion initiatives to 
substantially reduce such technical barriers on trade. The study indicated correlations were statistically significant given that the $\mathrm{p}$ value was $<0.05$ suggesting that an increase in country relations increase export volume, value but except profitability and the vice versa

\section{Conclusion}

The study assessed that many issues of trade liberalization remain to appear, greater benefits was obtained by removing technical barriers on nondiscriminatory or through the removal of protectionist measures based on standards. It suggests that maximizing outcomes of the trade sector requires good country relations together capable of creating an enabling environment, easing access to information regarding export market requirements and simplifying processes.

The study confirms that the link between international trade and export promotion is stronger, but for some clusters those exporting smaller quantities are gaining more profit than the ones exporting in bigger quantities. To benefit from international trade, Rwanda needs to add value to products; thus improving on both the quality and quantity of goods to be exported.

\section{Acknowledgments}

I wish to acknowledge Dr. Kamande Mercyline for her contribution to this work. I wish to extend my acknowledgement to Mount Kenya University, National Agricultural Export Board (NAEB), Ministry of Trade and Industry (MINICOM), National Institute of Statistics of Rwanda (NISR) and National Bank of Rwanda (BNR) authorities

\section{References}

[1] Ahmed, A.K. (2011). An Analysis of Regional Integration in Southern Africa: A South African Perspective. Tralac Paper. Western Cape. South Africa.

[2] Asika, N. (2010). Research Methodology in the Behavioural Sciences. Ikeja: Longman.

[3] Blaxter, L., Hughes, C.,\& Tight, M. (2010).How to Research, $2^{\text {nd }}$ Ed. (Open University Press, Celtic Court 22 Ballmoor Buckingham MK18 1XW).

[4] Bosse, E. (2013). Tariffs, Non-Tariff Measures and Imports A comparison of econometric approaches to estimate the gravity equation. Master's Thesis of University of New York.

[5] Bru“ckner, M. \& Daniel, L. (2012).Trade Causes Growth in Sub-Saharan Africa. The
World Bank Policy Research Working Paper no. 6007.

[6] Burger, M. \&Linders, C. (2009).On the Specification of the Gravity Model of Trade: Zeros, Excess Zeros and ZeroInflated Estimation. Department of Economic Geography, Utrecht University and Environmental Assessment. Rotterdam.

[7] Burstein, A. \&Melitz, M. (2013).Trade Liberalization and Firm Dynamics. [ebook] Available at: https://scholar.harvard.edu/files/melitz/files/ wc_final.pdf. Accessed on $17^{\text {th }}$ January, 2020.

[8] Chidede, T. (2017).Recent FDI trends in Africa: Summary analysis of the UNCTAD World Investment Report 2017. [online] tralac. Available at: https://www.tralac.org/discussions/article/1 1778-recent-fdi-trends-in-africasummaryanalysis-of-the-unctad-worldinvestment-report-2017.html. Accessed on August $13^{\text {th }}, 2019$.

[9] Chidede, T. (2018).World Trade Organization Trade Facilitation Agreement: An African Perspective. Accessed from: https://www.tralac.org/blog/article/13680wto-trade-facilitation-agreement-an-africanperspective.html.Accessed on October $27^{\text {th }}$, 2019.

[10] Daniel, J. A. \& Isaac. H. (2017). The Effects of Trade and Trade Facilitation on Economic Growth in Africa. African Development Review, 2017, vol. 29, issue 2, 350-361.

[11] Donna, L. \& Hocking, B. (2010). Economic Diplomacy in Robert A. Denemark (ed.) The International Studies Encyclopedia, Vol. II, pp 1216-1227. Wiley Blackwell.

[12]Egger, P. \& Michael, P. (2014).“The Impact of Bilateral Investment Treaties on Foreign Direct Investment," Journal of ComparativeEconomics.

[13] Fontagné, L., Guillin, A., \&Mitaritonna, C. (2011).Estimations of Tariff Equivalents for the Service Sectors. CEPII Working Paper No 2011-24

[14]He, Y. (2013). Does China's Trade Expansion Help African Development?-An Empirical Estimation. China Economic Review 26, 28-38

[15] Kanyimbo, P. \&Manduna, C. (2013).Trade Facilitation in the Bali Package: What's in it for Africa? Retrieved on February 13, 2020from: http://www.afdb.org/en/blogs/integrating- 
africa/post/trade-facilitation-inthe-balipackage-whats-in-it-for-africa-12698/.

[16] National Bank of Rwanda [BNR].(2018). 2018-2019 Annual Reports (2015-2019). Kigali, January 2020.

[17] O'Neil, J. (2016). Accession to the World Trade Organization: Sector Level Impacts on Extensive and Intensive Margins of Trade. Retrieved from: https://tcb.usaid.gov/prepared/literature_rev iew wto accession and economic growth. pdf-Incomplete on October $14^{\text {th }}, 2019$.

[18] Pearson, M. \&Chaitezvi, R. (2012).Welfare Implications of COMESA-EAC-SADC Tripartite Free Trade Area. African Development Review 26(1).

[19]Rose, C. (2007).Does female board representation influence firm performance? The Danish evidence. Journal of International Economic Affairs, Vol.4 No.5, May 25, 2017

[20]Rwanda Revenue Authority [RRA].(2017).Quarterly Customs and Trade Statistics. Kigali. Rwanda

[21]Rwanda Revenue Authority [RRA].(2017).Annual Reports (2015-2019). Kigali. Rwanda

[22] Saner, R., \&Yiu, L. (2014). Business Diplomacy Competence: A Requirement for
Implementing the OECD's Guidelines for Multinational Enterprises. The Hague Journal of Diplomacy, 9(4), 311-333.

[23] Seetanah, B., Sannasee, R., Tandrayen, V. \&Lamport, M. (2013).Non-Tariff Barriers within the COMESA Region: The Possibility of a Penalty System. Thesis for University of Mauritius.

[24] World Trade Organization [WTO].(2010). What Constrains Africa's Exports? Geneva. Retrieved from: https:// WWW

.wto.org/english/res e/reser_e/ersd201007 e.pdf on October $25^{\text {th }}, 2019$.

[25] World Bank [WB]\&World Trade Organization[WTO].(2015).The Role of Trade in Ending Poverty. Retrieved from: https://www.wto.org/english/res e/booksp e/world bank and wto 15 e.pdf on October $25^{\text {th }}, 2019$.

[26] World Trade Organization [WTO].(2018).Mainstreaming Trade to Attain Sustainable Development Goals. Retrieved from: https://www.wto.org/english/res_e/publicati ons_e/sdg_e.htm. Accessed on October ${ }^{29 t h}$, 2019. 